Journal

of Geography,

Politics and Society

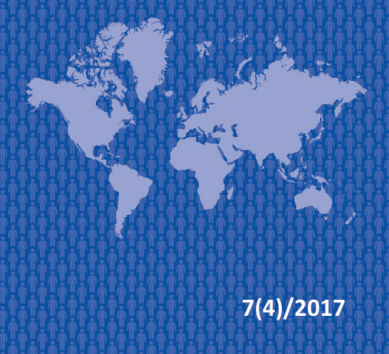

\section{Journal of Geography, Politics and Society}

$2017,7(4), 57-63$

DOI 10.4467/24512249JG.17.039.7639

\title{
CHANGES IN THE NUMBER OF POPULATION IN LARGE CITIES OF CENTRAL AND EAST-CENTRAL EUROPE
}

\author{
Łukasz Marszałek \\ Institute of Geography and Regional Studies, Pomeranian University in Słupsk, Partyzantów 27, 76-200 Słupsk, Poland, \\ e-mail: lukasz.marszalek@apsl.edu.pl
}

\section{Citation}

Marszałek Ł., 2017, Changes in the number of population in large cities of Central and East-Central Europe, Journal of Geography, Politics and Society, 7(4), 57-63.

\begin{abstract}
The aim of the article is to review the situation in terms of changes in the population of large cities in Central and East-Central Europe. Cities with a population above 300,000 inhabitants in 2004 were considered as large. The time frame of the analysis covers the period between 2004 and 2014. In total, the study involved 59 cities, of which in 31 an increase in the official number of inhabitants was recorded, and in 29 a decrease. It was found that the largest increase occurred mainly in the capital cities and in cities attractive to tourists, while the biggest decrease in post-industrial cities. At the regional level, the highest percentage of large cities with a decrease in the official population was recorded in the Baltic States, Poland and Ukraine.
\end{abstract}

\section{Key words}

big cities, shrinking cities, Central Europe, Central and Eastern Europe.

\section{Introduction}

Since the fall of the Communist system in Europe, we have been observing increasingly faster processes of depopulation in Central and East-Central Europe. As a result, currently the vast majority of countries of the region are characterised by an unfavourable demographic situation and a decrease in population (cf. Berzis, Zvidrins, 2011; Michalski, 2005; 2010; Rybicka, 2014; The impact ..., 2011), which to a large extent results from unfavourable trends in the birth and death rates. Another factor worsening the already unfavourable demographic situation in this region is large emigration which in the vast majority of cases goes unnoticed by official statistics (see Neguț et al., 2010, Szołtys, 2016). Unsurprisingly, then, the demographic forecasts for the countries of the region are pessimistic (cf. Matysiak, Nowok, 2006; Манаков, Суворков, 2017; Позняк, Шевчук, 2014).

Of course, in the context of particular countries in the region or the types of settlement, the situation looks a little different. Thus in the case of large cities, an additional factor strongly influencing changes in the number of their population is the suburbanisation process (cf. Dzhaman, 2011; Grigorescu et al., 2012; Karachurina, Mkrtchyan, 2015; Kubeš, 2013; Śleszyński, 2006). 


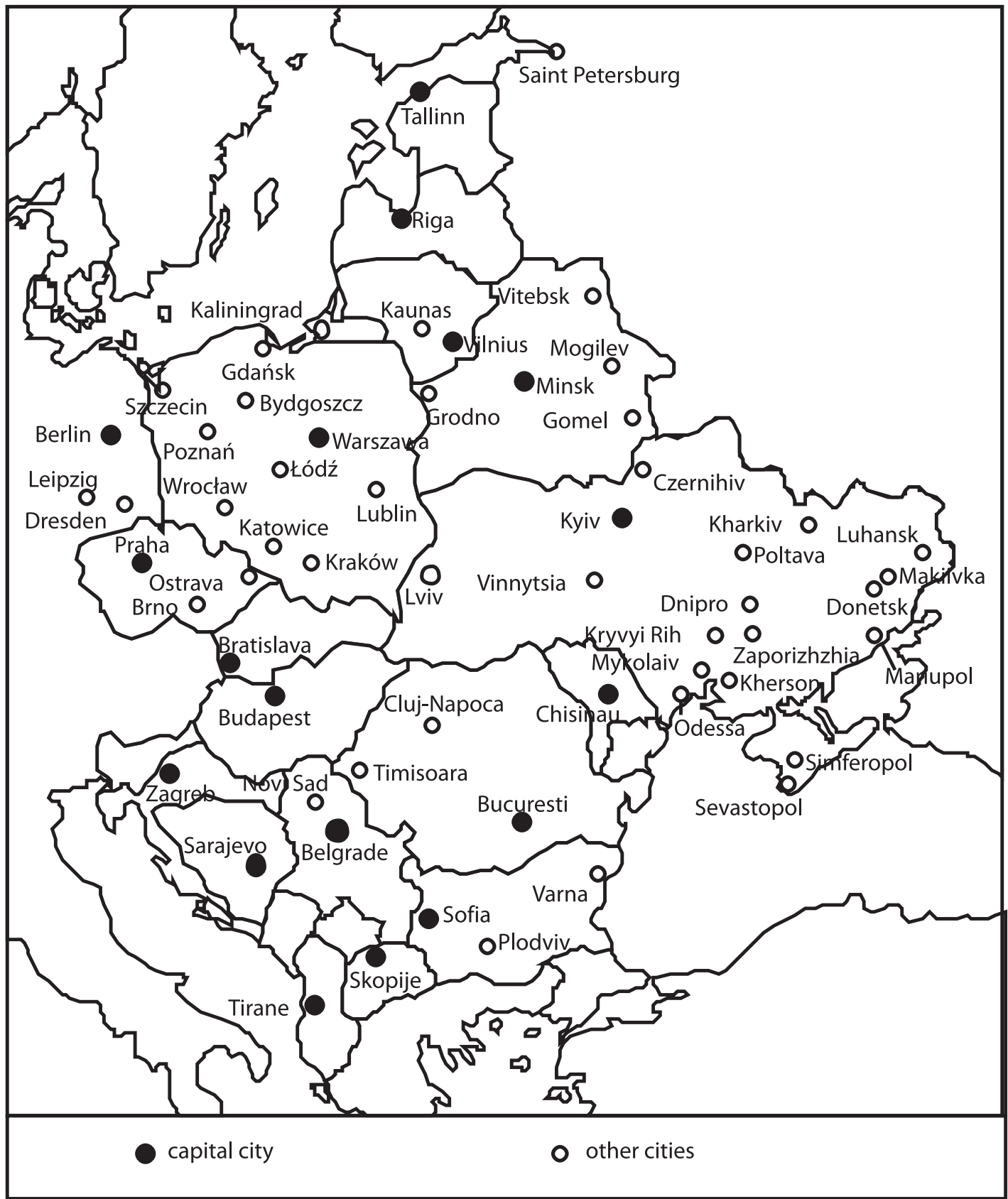

Fig. 1. Analysed cities

Source: own study.

J.J. Parysek (2005), basing on Polish cities, has identified several factors of their transformations. These factors can be applied to all large post-socialist cities in the analysed region:

1) Endogenous factors:

a) the systemic transformation;

b) demographic and social changes;

c) local factors and limitations on growth.

2) Exogenous factors:

a) changes of the post-industrial (post-modern) period:

b) globalisation and metropolitanisation and their effects on cities; c) European integration.

This article focuses on the endogenous factor associated with the demographic changes. To this end, changes in the number of the population of large cities of post-socialist countries in Europe were analysed. In this type of analysis there are various limits for the notion of a large city'. Different ones will be in a small country, and different ones in a large one. For this study we have adopted a limit of 300,000 residents in 2004, and we tried to take into account the population living in the administrative borders

1 For example, M. Viturka (2016) adopted a limit of 500,000 inhabitants. 
of the city ${ }^{2}$. The time frame of the analysis covers the period of $2004-2014^{3}$, i.e. since the beginning of the expansion of the European Union to the East of the continent until the last year for which complete data were obtained. The spatial range covers almost all post-Communist European countries, except that for Russia only Kaliningrad and Saint Petersburg were taken for analysis. On the other hand, large cities of the former GDR were also included in the analysis. As a result, 60 cities were designated for analysis, of which 18 are capital cities (fig. 1). Because of the difficulty in obtaining reliable data, Sarajevo was excluded from analysis, hence 59 cities were finally studied.

\section{Analysis of changes in the number of the population}

The data presented in Fig. 2. seem to contradict the widespread belief that big cities in Central and East-Central Europe are becoming depopulated. It is clear that in the capitals of the countries (with the exception of Riga, Vilnius and Bratislava) a growing number of the population is recorded. One can, therefore, be tempted to declare that this group of cities "won" the impact of exogenous factors defined by J.J. Parysek (2005). This is confirmed by individual studies of these cities (Keivani et al., 2002; Kohlbacher, Protasiewicz, 2012; Pojani, 2010; Stadion, Mollov, 2000; Zlatar 2014). On the opposite side we have the so-called monocities, or more generally, the former industrial cities, in which there was the greatest fall in the population numbers: Ostrava, Makiivka, Kherson, Luhansk, Łódź, Katowice, Poltava, Mariupol, Dnipro, Donetsk, Zaporizhzhia, Kaunas. In the case of these cities the synergistic effect of a series of negative factors is amplified by their economic problems ${ }^{4}$ (Gołata, Kuropka, 2016; Krzysztofik, Runge, 2010; Krzysztofik et al. 2011, 2014; Mykhnenko, 2010; Ogrodowczyk, Marcińczak, 2014; Rumpel et al., 2010, 2014; Spóra et al., 2016). It is also noticeable that cities which are attractive tourist destinations are characterized by more favourable changes in the population, examples being Saint Petersburg in Russia, Gdansk and Krakow in Poland, Lviv, Odessa

\footnotetext{
2 One clear exception was made for Novi Sad, for which the population was counted together with the city of Petrovaradin, situated on the other bank of the Danube.

3 Although in some cases (due to difficulties in the availability of data) slightly different time ranges were adopted, which was cleared mentioned.

4 This regularity also concerns much smaller post-industrial cities (cf. Jaroszewska, 2014; Krupa, Krul, 2012; Szymańska 2007, 2010, 2011; Добрейцина, 2013; Левинтов, 2014).
}

and Sevastopol in Ukraine, or Varna in Bulgaria. Their internal vitality and traditions and a greater diversification of the economy meant that these cities more quickly adapted to the new exogenous factors. And the mere fact of their high tourist attractiveness (cf. Berbeka et al., 2011; Shabliy, 2017; Stetsiuk, Michalski, 2012; Tölle, 2008) is the differentiator of better living conditions they offer as well as greater possibilities to adapt to new socio-economic realities.

In turn, looking at the situation in the regional depiction, we can observe three areas where there was a clear reduction in the number of population in large cities. Firstly, these are the Baltic States ${ }^{5}$, in which a particularly high population decline was noted not only in big cities, but generally in the urban population. Foreign emigration is an important factor in reducing the population number of large cities $^{6}$ (cf. Kosov, Mikheeva, 2010; Michalski, 2012). Large cities with declining population prevail also in Poland. In their case, the reason is both a negative migration balance (both internal in the city/village pair, and international), and with the negative birth rate (cf. Kaczmarek et al., 2011; Zborowski et al., 2012). However, the biggest population losses were recorded in large cities of Ukraine. These are mainly caused by a clearly negative birth rate and high emigration abroad, and this results from badly implemented political and economic transformation (cf. Kuczabski, Michalski, 2014; Radchenko et al., 2014; Кучабський, 2014).

On the other hand, the increasing number of the population of the cities in Belarus is puzzling. Taking into account the processes of depopulation in that country (Ноздрин-Плотницкая, 2016) - the main explanation may be significant internal immigration to large cities (cf. Красовский, 2012), which of course does not exclude the suburbanisation processes (cf. Сулим, 2016).

\section{Conclusions}

In view of the above, one should ask a question whether so often presented processes of shrinking cities in the analysed part of Europe (cf. Friedrich et al., 2014; Jaroszewska, Stryjakiewicz, 2014; Schoenberg, Constantin, 2014; Stryjakiewicz, 2013; Stryjakiewicz, Jaroszewska, 2016; Zborowski et al., 2012) are actually related to large cities? The results of the

\footnotetext{
5 Although officially the population of Tallinn has increased, the number of urban population in Estonia is falling.

6 Which, by the way, has lasted since regaining independence, although initially this was emigration to Russia, and now to the rich EU countries.
} 


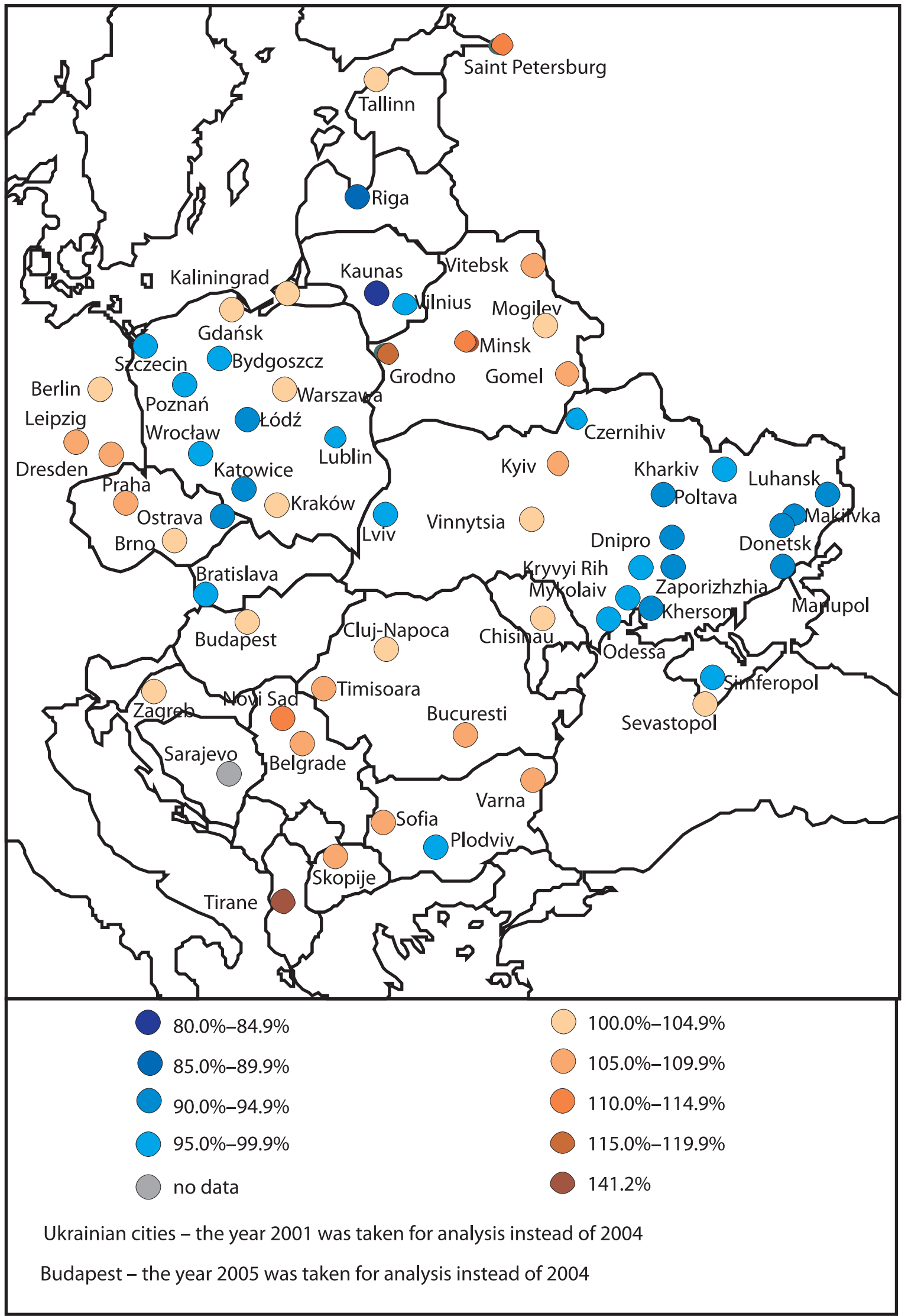

Fig. 2. Change in the official number of inhabitants 2004-2014 (2004=100\%)

Source: own study based on: Population on 1 January by age groups and sex - cities and greater cities [urb_cpop1] and dispersed data. 
presented analysis are ambiguous, because out of 59 analysed cities an increase in the official population was noted in 31 of them, and a decrease in 28.

It is clear that the depopulation processes hardly ever concern cities which are the capitals of countries and which have a high potential as tourist destinations; however, to a very large extent they concern post-industrial cities. We can also notice a very large diversity of the situation in the regional approach. Nevertheless, given the adverse demographic forecasts, it can be concluded that the number of major cities in which the population will gradually decrease in the next few years will grow.

\section{References}

Banca de date "Statbank", Biroul Național de Statistică al. Republici Moldova, Chișinău, http://statbank. statistica.md/pxweb/pxweb/en/60\%20Statistica\%20regionala/?rxid=b2ff27d7-0b96-43c9-934b42e1a2a9a774 [20.05.2017].

Berbeka J., Borodako K., Klimek K., Niemczyk A., Seweryn R., 2011, Kraków miastem kongresów - stan obecny i perspektywy rozwoju (na przykładzie badań turystyki MICE w 2008 roku), Ekonomiczne Problemy Turystyki, 15, 7-19.

Berzins A., Zvidrins P., 2011, Depopulation in the Baltic States, Lithuanian Journal of Statistics, 50(1), 39-48.

Dzhaman V., 2011, Territorial structure of the West-Ukrainian region settling system, Słupskie Prace Geograficzne, 8, 27-36.

Friedrich P., Ülper A., Ukrainski K., 2014, Shrinking cities and processes in Estonia, [in:] H.W. Richardson, Ch.W. Nam (eds.), Shrinking cities. A global perspective, Routledge, London-New York, 119-137.

Gołata E., Kuropka I., 2016, Large cities in Poland in face of demographic changes, Bulletin of Geography. Socio-economic Series, 34, 17-31.

Grigorescu I., Mitrică B., Moczanu I., Ticană N., 2012, Urban spraw land residential development in the Romanian metropolita areas, Revue Roumaine de Géographie / Romanian Journal of Geography, 56(1) 43-59.

Jaroszewska E., 2014, Wałbrzych - dziedzictwo przeszłości a wyzwania przyszłości, [in:] T. Stryjakiewicz (ed.), Kurczenie się miast w Europie Środkowo-Wschodniej, Bogucki Wydawnictwo Naukowe, Poznań, 102-113.

Jaroszewska E., Stryjakiewicz T., 2014, Kurczenie się miast w Polsce, [in:] T. Stryjakiewicz (ed.), Kurczenie się miast w Europie Środkowo-Wschodniej, Bogucki Wydawnictwo Naukowe, Poznań, 67-77.

Kaczmarek T., Kaczmarek U., Bul R., 2011, Analiza relacji funkcjonalnych aglomeracji poznańskiej z otoczeniem regionalnym (w kontekście dyfuzyjno-absorpcyjnego modelu rozwoju), Centrum Badań Metropolitalnych Instytut Geografii Społeczno-Ekonomicznej i Gospodarki Przestrzennej Uniwersytet im. Adama Mickiewicza w Poznaniu, Poznań.
Karachurina L., Mkrtchyan N., 2015, Population change in the regional centers and internal periphery of the regions in Russia, Ukraine and Belarus over the period of 19902000s, Bulletin of Geography. Socio-economic Series, 28, 91-111.

Keivani R., Parsa A., McGreal S., 2002, Institutions and Urban Change in a Globalising World: The Case of Warsaw, Cities, 19(3), 183-193

Kohlbacher J., Matusz Protasiewicz P., 2012, Policies on intergroup relations in Central and East European cities: a comparative analysis of Budapest, Prague, Wrocław and Tallinn, Miscellanea Geographica - Regional Studies Development, 16(2), 5-10.

Kosov Y., Mikheeva N., 2010, The demographic problem of the Baltic cities: general trends, The Baltic Region, 4(6), 5-14.

Krupa L., Krul M., 2012, Usti nad Łabą - ocena i perspektywy rozwoju czeskiego miasta poprzemysłowego, [in:] S. Kornik, A. Mempel-Śnieżyk (eds.), Wybrane problemy współpracy polsko-czeskiej: gospodarka i infrastruktura, Wydawnictwo Uniwersytetu Ekonomicznego we Wrocławiu, Wrocław, 48-57.

Krzysztofik R., Rrunge J., 2010, Urban shrinkage in Bytom and Sosnowiec, the Katowice Conurbation, Poland, series: SHRiNK SMaRT WP2-D4, https://www.ufz.de/export/ data/400/39017_WP2_report_Sosnowiec_Bytom_kompr.pdf [23.06.2017].

Krzysztofik R., Runge J., Kantor-Pietraga I., 2011, Paths of Shrinkage in the Katowice Conurbation. Case Studies of Bytom and Sosnowiec Cities, Uniwersytet Śląski, Sosnowiec.

Krzysztofik R., Runge A., Runge J., Kantor-Pietraga I., 2014, Miasta konurbacji katowickiej, [in:] T. Stryjakiewicz (ed.), Kurczenie się miast w Europie Środkowo-Wschodniej, Bogucki Wydawnictwo Naukowe, Poznań, 89-101.

Kubeš J., 2013, European post-socialist cities and their near hinterland in intra-urban geography literature, Bulletin of Geography. Socio-economic Series, 19, 19-43.

Kuczbski A., Michalski T., 2014, Ukrainian post-communist transformation: causes, consequences and threats, Quaestiones Geographicae, 33(2), 171-180

Matysiak A., Nowok B., 2006, Stochastic forecast of the population of Poland, 2005-2050, series: MPIDR WORKING PAPER WP 2006-026, http://www.demogr.mpg.de/papers/working/wp-2006-026.pdf. [19.06.2017].

Michalski T., 2005, Changes in the Demographic and Health Situation Among Post-Communist Members of the European Union, Wydawnictwo „Bernardinum”, Pelplin.

Michalski T., 2010, Sytuacja zdrowotna w europejskich krajach postkomunistycznych $w$ dobie transformacji, Wydawnictwo Uniwersytetu Gdańskiego, Gdańsk.

Michalski T., 2012, Przemiany w liczbie ludności i ruchu rzeczywistym w Europie Środkowej i Środkowo-Wschodniej w okresie transformacji, Wydawnictwo „Bernardinium”, Pelplin.

Municipalities and regions in the Republic of Serbia, 2016 Population, Републички завод за статистику, Београд, http://webrzs.stat.gov.rs/WebSite/Public/PageView. aspx?pKey=164 [20.05.2017]. 
Municipalities of Serba 2010 - Population, Републички завод за статистику, Београд, http://webrzs.stat.gov.rs/WebSite/Public/PageView.aspx?pKey=164 [20.05.2017].

Mykhnenko V., Myedvyedyev D., Kuzienko L., 2010, Urban shrinkage in Donetsk and Makiivka, the Donetsk conurbation, Ukraine, series: SHRiNK SMaRT WP2 D4, https://www. ufz.de/export/data/400/39019_WP2_report_Donetsk_ Makiivka_NEW_kompr.pdf [23.06.2017].

Neguț S., di Comite L., Neacşu M-C., 2010, Immigration - Socio-economical Implications. The Case of Romania, Amfiteatru Economic, 12(28), 576-593.

Ogrodowczyk A., Marcińczak S., 2014, Łódź - od polskiego Manchesteru do polskiego Detroit, [in:] T. Stryjakiewicz (ed.), Kurczenie się miast w Europie Środkowo-Wschodniej, Bogucki Wydawnictwo Naukowe, Poznań, 79-88.

Parysek J.J., 2005, Development of Polish tows and cities and factors affecting this process and the turn of the century, Geographia Polonica, 78(1), 99-116.

Pojani D., 2010, Tirana, Cities, 27(6), 483-495.

Population 2001-2016 by prefectures, Instituti i Statistikave, Tiranë, http://www.instat.gov.al/en/themes/population. aspx [19.05.2017].

Population estimate of the Republic of Croatia (kode: FR 7.1.4), Državni zavod za statistiku, Zagrzeb, http://www.dzs.hr/ default_e.htm [20.05.2017].

Population on 1 January by age groups and sex - cities and greater cities [urb_cpop1], last update: 21.12.2016, EUROSTAT: http://ec.europa.eu/eurostat/web/cities/data/database [19.05.2017].

Radchenko A., Kuczbaski A., Michalski T., 2014, Main factors affecting the cosial transformation process in Ukraine, Journal of Geography, Politics and Society, 1(7), 5-18.

Rumpel P., Siwek T., Slach O., 2014, Czy Ostrawa jest kurczącym się miastem? [in:] T. Stryjakiewicz (ed.), Kurczenie się miast w Europie Środkowo-Wschodniej, Bogucki Wydawnictwo Naukowe, Poznań, 61-65.

Rumpel P., Slach O., Tichá I., Bednáŕ P., 2010, Urban shrinkage in Ostrava, Czech Republic, series: series: SHRiNK SMaRT WP2 D4, https://www.ufz.de/export/data/400/39016_ WP2_report_Ostrava.pdf [23.06.2017].

Rybicka K., 2014, Problemy demograficzne w Polsce i wybranych krajach Unii europejskiej, [in:] M. Kaczmarska, I. Pietrka (eds.), Problemy gospodarki światowej. Tom IV, Instytut Badań Gospodarczych, Polskie Towarzystwo Ekonomiczne Oddział w Toruniu, Toruń, 231-245.

Schoenberg A.M., Constantin D.L., 2014, Urban shrinkage in Romania. Scope and determinants, [in:] H.W. Richardson, Ch.W. Nam (eds.), Shrinking cities. A global perspective, Routledge, London-New York, 105-118.

Shabliy O., 2017, Human and geographical analysis of historical and cultural heritage of Lviv, Journal of Geography, Politics and Society, 7(2), 48-63.

Śleszyński P., 2006, Demograficzny wymiar procesów suburbanizacji w Polsce po 1989 roku, [in:] S. Kozłowski (ed.), Żywiołowe rozprzestrzenianie się miast. Narastający problem aglomeracji miejskich w Polsce, Ekonomia i Środowisko, Warszawa, 105-124.

Spóra T., Kantor-Pietraga I., Krzysztofik R., 2016, Trajectories of depopulation and urban shrinkage in the Katowice
Conurbation, Poland, Espace populations sociétés, 2015/32016/1, 1-20.

Stadion C., Mollov B., 2000, City profile: Sofia, Bulgaria, Cities, 17(5), 379-387.

Stetsiuk O., Michalski T., 2012, Lviv - Ukraine, [in:] W. Cudny, T. Michalski, R. Rouba (eds.), Tourism and the transformation of large cities in the post-communist countries of Central and Eastern Europe, Wydawnictwo Uniwersytetu Łódzkiego, Łódź, 115-128.

Stryjakiewicz T., 2013, Proces kurczenia się miast (urban shrinkage) i jego konsekwencje, [in:] W.M. Gaczek (ed.), Dynamika, cele i polityka zintegrowanego rozwoju regionów. Aspekty teoretyczne i zarządzanie w przestrzeni, Bogucki Wydawnictwo Naukowe, Poznań, 125-135.

Stryjakiewicz T., Jaroszewska E., 2016, The process of shrinkage as a challenge to urban governance. Quaestiones Geographicae, 35(2), 27-37.

Szołtys D., 2016, Migracje zagraniczne w Polsce, [in:] Sytuacja demograficzna Polski. Raport 2015-2016, Rządowa Rada Ludnościowa, Warszawa, 148-174.

Szymańska W., 2007, Rozwój demograficzny miast średniej wielkości na tle przemian ludnościowych regionów nadmorskich (ze szczególnym uwzględnieniem Wałcza, Szczecinka i Lęborka), Słupskie Prace Geograficzne, 3, 5572.

Szymańska W., 2010, Przeobrażenia demograficzne i zmiany wewnątrzmiejskiej struktury zaludnienia w Koszalinie w latach 1988-2008, [in:] S. Liszewski (ed.), Obszary metropolitalne we współczesnym środowisku geograficznym, 58. Zjazd Polskiego Towarzystwa Geograficznego, Oddział Łódzki PTG, Wydział Nauk Geograficznych UŁ, Łódź, 167-175

Szymańska W., 2011, Społeczna przestrzeń w średnich miastach na Pomorzu (przykład Lęborka, Szczecinka i Wałcza), Akademia Pomorska w Słupsku, Słupsk

The impact of European demographic trends on regional and urban development. Synthesis report, 2011, Hungarian Presidency of the Council of the European Union, Budapest, https://www.mmr.cz/getdoc/b5f015cc-bb36-402988f8-33a2d2e61ec6/Demograficke-zmeny [05.06.2017]

Tölle A., 2008, Gdańsk, Cities, 25(2), 107-119.

Viturka M., 2016, Metropole Střední Europy, [in:] Výroční konference České geografické společnosti, Jihočeská univerzita v Českých Budějovicích, Pedagogická fakulta, katedra geografie, České Budějovice, 227-234.

Zborowski A., Soja K., Łobodzińska A., 2012, Population trends in Polish cities - stagnation, depopulation or shrinkage? Prace Geograficzne IGiPZ UJ, 130, 7-28.

Zlatar J., 2014, Zagreb, Cities, 39, 144-155.

Всеукраїнський перепис населення '2001, Державний комітет статистики України, Київ, http://2001.ukrcensus. gov.ua/ [20.05.2017].

Демографический ежегодник Республики Беларусь, 2012, Национальный статистический комитет Республики Беларусь, Минск.

Демографический ежегодник Республики Беларусь, 2016, Национальный статистический комитет Республики Беларусь, Минск. 
Добрейцина Л.Е., 2013, Брендинг индустриального города: поиск смыслов, проблемы и перспективы (на материале Нижнего Тагила), Лабиринт. Журнал социальногуманитарных исследований, 5, 80-88.

Красовский К.К., 2012, Геодемографическое развитие городских структур Беларуси в начале XXI в., Весці БДПу. Серыя 3, 3, 35-39.

Кучабський О.Г., 2014, Геополітичне майбутнє України: сценарії розвитку, Публічне управління: теорія та практика, 4, 8-16.

Левинтов А.Е., 2014, Экзогенные и эндогенные факторы регенерации индустриальных моногородов, Лабиринт. Журнал социально-гуманитарных исследований, 1, 89-97.

МАКСтат - база на податоци, Државен завод за статистика, Скопје, http://makstat.stat.gov.mk/PXWeb/ pxweb/mk/MakStat/?rxid=46ee0f64-2992-4b45-a2d9cb4e5f7ec5ef [19.05.2017].

Манаков А.Г., Суворков П.Э., 2017, Моделирование демографического развития стран Центральной и Восточной Европы в XXI веке, Известия Русского географического общества, 149(2), 3-15.

Міста України (за населенням), https://uk.wikipedia.org/wi ki/\%D0\%9C\%D1\%96\%D1\%81\%D1\%82\%D0\%B0_\%D0 \%A3\%D0\%BA\%D1\%80\%D0\%B0\%D1\%97\%D0\%BD\%D0 \%B8_(\%D0\%B7\%D0\%B0_\%D0\%BD\%D0\%B0\%D1\%81\% D0\%B5\%D0\%BB\%D0\%B5\%D0\%BD\%D0\%BD\%D1\%8F\% D0\%BC) [20.05.2017].

Ноздрин-Плотницкая А.И., 2016, Решение проблемы депопуляции в Беларуси в контексте зарубежного опыта, [in:] Е.А. Антипова (ed.), Демографические риски XXI века (к Международному дню народонаселения), Белсэнс, Минск, 104-105.

Позняк А.В., Шевчук П.Е., 2014, Демографические перспективы Украины до 2060 года, Демогрфія та сочіальная економіка, 1(21), 72-84.

Регионы России. Основные социально-экономические показатели городов, 2004, Федеральная служба государственной статистики, Москва, http://www.gks.ru/bgd/ regl/b04_54/Main.htm [19.05.2017].

Регионы России. Основные социально-экономические показатели городов, 2014, Федеральная служба государственной статистики, Москва, http://www.gks.ru/bgd/ regl/b14_14t/Main.htm [19.05.2017].

Сулим С.Н., 2016, Особенности демографического развития малых городов Беларуси в зонах влияния региональных центров, [in:] Е.А. Антипова (ed.), Демографические риски XXI века (к Международному дню народонаселения), Белсэнс, Минск, 121-123. 